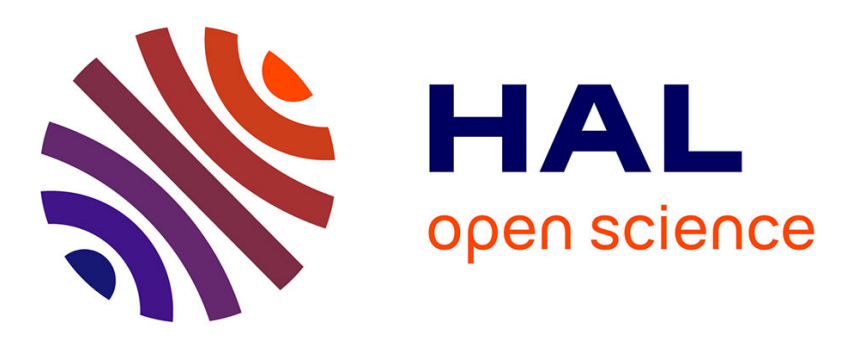

\title{
Complications of dexamethasone prescribed for Streptococcus pneumoniae meningitis associated with cerebral vasculitis involving large- to medium-sized vessels
}

A Corchia, A Gouvion, S Deguelte-Lardiere, V Vernet Garnier, P Raclot, Y N'guyen

\section{To cite this version:}

A Corchia, A Gouvion, S Deguelte-Lardiere, V Vernet Garnier, P Raclot, et al.. Complications of dexamethasone prescribed for Streptococcus pneumoniae meningitis associated with cerebral vasculitis involving large- to medium-sized vessels. Revue Neurologique, 2017, 174, pp.267 - 268. 10.1016/j.neurol.2017.06.024 . hal-03267293

\section{HAL Id: hal-03267293 \\ https://hal.science/hal-03267293}

Submitted on 24 Jun 2021

HAL is a multi-disciplinary open access archive for the deposit and dissemination of scientific research documents, whether they are published or not. The documents may come from teaching and research institutions in France or abroad, or from public or private research centers.
L'archive ouverte pluridisciplinaire HAL, est destinée au dépôt et à la diffusion de documents scientifiques de niveau recherche, publiés ou non, émanant des établissements d'enseignement et de recherche français ou étrangers, des laboratoires publics ou privés. 


\section{Complications of dexamethasone prescribed for Streptococcus pneumoniae meningitis associated with cerebral vasculitis involving large- to medium-sized vessels}

A Corchia, A Gouvion, S Deguelte-Lardiere, V Vernet Garnier, P Raclot, Y N'guyen

\section{To cite this version:}

A Corchia, A Gouvion, S Deguelte-Lardiere, V Vernet Garnier, P Raclot, et al.. Complications of dexamethasone prescribed for Streptococcus pneumoniae meningitis associated with cerebral vasculitis involving large- to medium-sized vessels. Revue Neurologique, Elsevier Masson, 2017, 174, pp.267 268. 10.1016/j.neurol.2017.06.024 . hal-03267293

\section{HAL Id: hal-03267293 \\ https://hal.archives-ouvertes.fr/hal-03267293}

Submitted on 24 Jun 2021

HAL is a multi-disciplinary open access archive for the deposit and dissemination of scientific research documents, whether they are published or not. The documents may come from teaching and research institutions in France or abroad, or from public or private research centers.
L'archive ouverte pluridisciplinaire HAL, est destinée au dépôt et à la diffusion de documents scientifiques de niveau recherche, publiés ou non, émanant des établissements d'enseignement et de recherche français ou étrangers, des laboratoires publics ou privés. 


\section{Letter to the editor}

\section{Complications of dexamethasone prescribed for Streptococcus pneumoniae meningitis associated with cerebral vasculitis involving large- to medium-sized vessels}

\begin{abstract}
A 57-year-old asplenic woman, suffering from Crohn's disease and experiencing fever for 7 days, was treated at another hospital with mesalazine (mesalamine) and ofloxacin based on the hypothesis of a Crohn's disease flare-up. Headache, neck stiffness and confusion arose in the last 2 days prior to her referral to our hospital (day 1) and before a brain computed tomography (CT) scan, showing a bilateral frontal ischemic lesion (with no mass effect), was performed. Lumbar puncture showed purulent cerebrospinal fluid (CSF) with purple diplococci after Gram staining. Ofloxacin was withdrawn, and a combined treatment associating cefotaxime $300 \mathrm{mg} / \mathrm{kg} /$ day and dexamethasone $10 \mathrm{mg}$ four times a day was started within $2 \mathrm{~h}$ of admission. The minimum inhibitory concentration (MIC) for the Streptococcus pneumoniae strain isolated from both CSF and blood cultures drawn on admission was $0.064 \mathrm{mg} / \mathrm{L}$. Antibiotic treatment was switched from cefotaxime to intravenous amoxicillin.
\end{abstract}

Thoracic CT confirmed that the portal of entry of the S. pneumoniae bacteremia was left lower lobe pneumonia. Austrian syndrome was ruled out, as bone scintigraphy evidenced left hip arthritis. Levofloxacin and co-trimoxazole were prescribed for 1 supplementary month after the end of the intravenous antibiotics. While the patient was no longer confused, cerebral magnetic resonance imaging (MRI), performed on day 3, revealed cerebral vasculitis (CV) involving medium and large vessels, such as the anterior and middle cerebral arteries (A1, M1/A2 and M2 segments; Fig. 1). As early discontinuation of dexamethasone (after 4 days) is recommended in cases of S. pneumoniae meningitis (SPM) because it can lead to a rebound effect and multiple cerebral infarctions [1], dexamethasone was left unchanged for 3 weeks before being tapered (Fig. 1). Also, because of the large-vessel involvement, it was preferable to administer high-dose steroids, which are recommended for giant cell arteritis, rather than to introduce cyclophosphamide, which is recommended for primary CV where the involvement of large vessels is not consistent [2].
Our patient became bedridden because of bilateral quadriceps atrophy, and she experienced acute pancreatitis due to cytomegalovirus (CMV) reactivation. Despite ganciclovir treatment, septic shock due to nosocomial peritonitis, related to the duodenal necrosis associated with CMV pancreatitis, arose on day 56. Surgical treatment consisted of a duodenumexcluding gastrojejunal anastomosis and an Oddi papillary surgical drainage procedure.

In the intensive care unit, dexamethasone was switched for hydrocortisone before steroid withdrawal after 93 days (Fig. 1). The outcome was favourable and the patient was discharged home from hospital after 6 months of rehabilitation. Her MiniMental State Examination and Rankin Scale scores were 29/30 and 2, respectively, 1-year later.

The case described here is of CV involving large- to medium-sized vessels that appeared after 2 days' evolution of SPM. Large-to-medium vessels are usually involved in bacterial-meningitis-associated CV and accounts for $0.5 \%$ of patients referred for strokes [3], whereas CV has been reported in 12 out of 87 cases of SPM [4]. In such cases, there are no recommendations concerning steroid treatment or adjunctive immunosuppressive therapy [3].

In our patient, the quadriceps atrophy that led to her bedridden state was due to dexamethasone: fluorinated glucocorticoids (including dexamethasone) are associated with a higher risk of muscle atrophy than non-fluorinated glucocorticoids (such as prednisone) [5]. This suggests that an immediate switch to a non-fluorinated corticosteroid or corticosteroid tapering should be discussed together with follow-up cerebral MRI, as an early switch to prednisone after 3 days of rapidly tapered dexamethasone has been associated with the development of chronic CV [6].

Thus, while gathering data to better define the optimal regime for steroids in CV associated with SPM, it is apparently important to immediately search for CV in cases of ischemic lesions as revealed on brain CT scans which, in our case here, were systematically performed. 


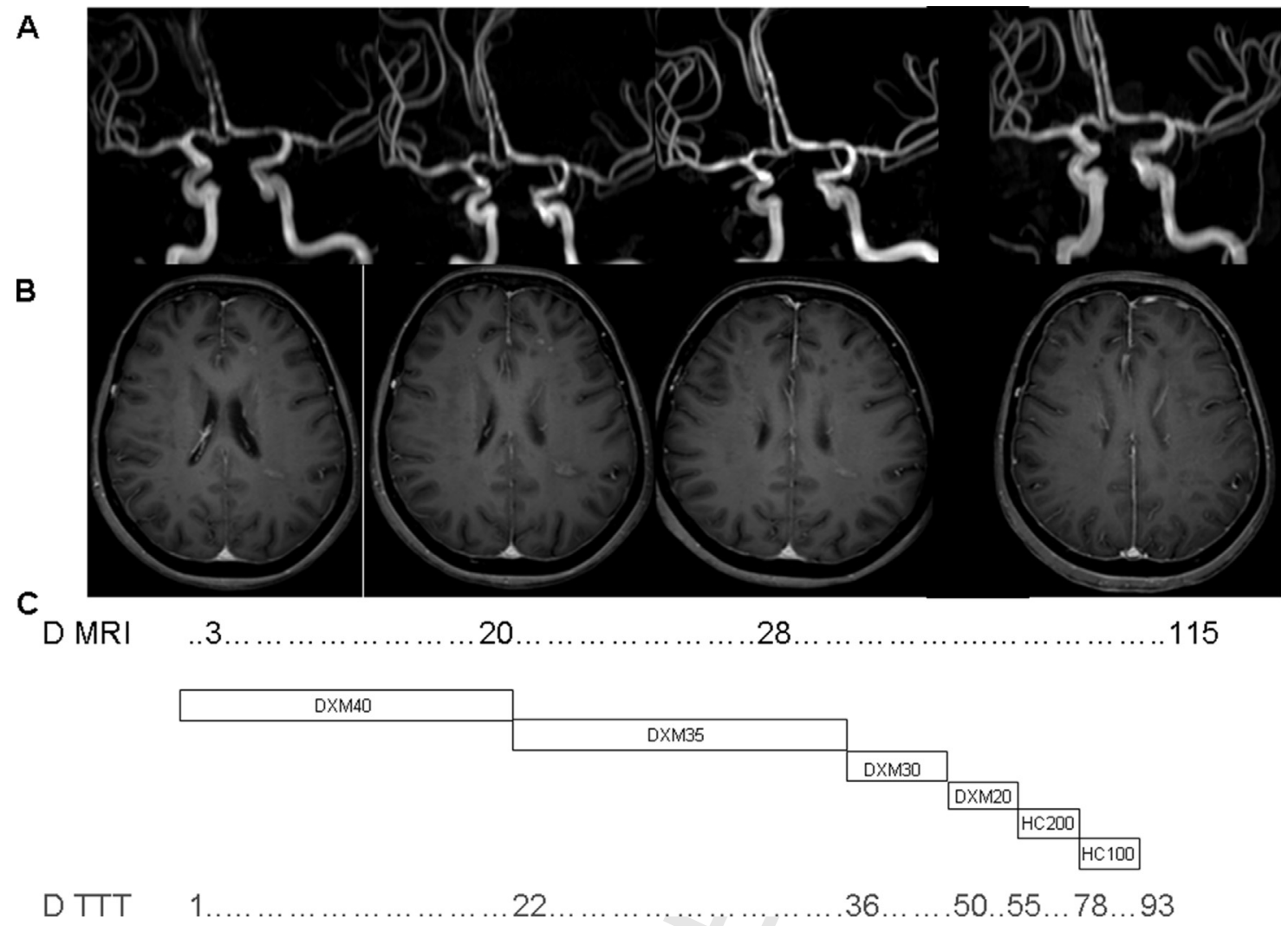

Fig. 1 - Cerebral magnetic resonance imaging (MRI) initially performed in our patient: (A) successive time-of-flight magnetic resonance angiography (TOF MRA) of the anterior and middle cerebral arteries reveals stenosis and dilatation of these arteries, giving a 'string of pearls' appearance; (B) successive T1-weighted post-gadolinium axial MRI sequences show blood-brain barrier ruptures in the anterior and middle cerebral artery territories; and (C) time scale in days (D) indicates when the MRI scans were performed and when the steroid treatment (TTT) was tapered (schematically depicted), with day 1 being the time of admission to our hospital. DXM: dexamethasone (daily dosage in mg); HC: hydrocortisone (daily dosage in $\mathrm{mg})$.

\section{Disclosure of interest}

The authors declare that they have no competing interest.

\section{Acknowledgements}

Daniele Fiquemont, Bernard Pignon, Sonia Baumard, Ahmed El Bekri.

\section{R E F E R E N C E S}

[1] Lefebvre N, Carre AC, Delabranche X, Guiot P, Mootien Y. Implication of dexamethasone adjunctive therapy after the onset of cerebral vasculitis in Streptococcus pneumoniae meningitis. Med Mal Infect 2007;37:118-20.

[2] Salvarani C, Brown Jr RD, Christianson T, Miller DV, Giannini C, Huston 3rd J, et al. An update of the Mayo Clinic cohort of patients with adult primary central nervous system vasculitis: description of 163 patients. Medicine (Baltimore) 2015;94:e738.
[3] Katchanov J, Siebert E, Klingebiel R, Endres M. Infectious vasculopathy of intracranial large- and medium-sized vessels in neurological intensive care unit: a clinicoradiological study. Neurocrit Care 2010;12:369-74.

[4] Kastenbauer S, Pfister HW. Pneumococcal meningitis in adults: spectrum of complications and prognostic factors in a series of 87 cases. Brain 2003;126:1015-25.

[5] Pereira RM, Freire de Carvalho J. Glucocorticoid-induced myopathy. Joint Bone Spine 2011;78:41-4.

[6] Czartoski T, Hallam D, Lacy JM, Chun MR, Becker K. Postinfectious vasculopathy with evolution to moyamoya syndrome. J Neurol Neurosurg Psychiatry 2005;76:256-9.

$$
\begin{aligned}
& { }_{\Lambda}^{\text {A. Corchia }}{ }_{\lambda}^{\mathrm{a}} \mathbf{Q 1} \\
& \text { A. Gouvion b } \\
& { }_{\Lambda} \text { S. Deguelte-Lardiere }{ }_{\lambda}^{c} \\
& { }_{\Lambda} V \text {. Vernet Garnier }{ }_{\Lambda}^{\mathrm{d}} \\
& { }_{\Lambda}^{\mathrm{P}} \text {. Raclotot } \\
& \text { Y. N'Guyen } n_{\lambda}^{\mathrm{f}, *}
\end{aligned}
$$

${ }^{a}$ Service de Néphrologie, Hôpital Maison Blanche, CHU Reims, 51092

Reims Cedex, France

${ }^{\mathrm{b}}$ Service de Radiologie, Hôpital Maison Blanche, CHU Reims, 51092 Reims Cedex, France

'Service de Chirurgie générale et digestive, Hôpital Robert Debré, CHU Reims, Rue du Général Koenig, 51100 Reims, France 
${ }^{\mathrm{d}}$ Laboratoire de Bactériologie, Hôpital Robert Debré, CHU Reims, Rue du Général Koenig, 51100 Reims, France

eUnité de Réanimation Polyualente, Hôpital Robert Debré, CHU Reims, Rue du Général Koenig, 51100 Reims, France ${ }^{f}$ Laboratoire de Virologie, EA 4684, UFR médecine Reims, 51 Avenue Cognacq Jay, 51100 Reims, France

*Corresponding author at: EA 4684, UFR médecine Reims, 51 Avenue Cognacq Jay, 51100 Reims, France. E-mail address: yohan.nguyen@wanadoo.fr (Y. N’Guyen)
Received 25 April 2017 Received in revised form 17 May 2017

Accepted 15 June 2017 Available online $\mathrm{xxx}$

https://doi.org/10.1016/j.neurol.2017.06.024 0035-3787/ (C) 2017 Elsevier Masson SAS. All rights reserved.

Please cite this article in press as: Corchia A, et al. Complications of dexamethasone prescribed for Streptococcus pneumoniae meningitis associated with cerebral vasculitis involving large- to medium-sized vessels. Revue neurologique (2017), https://doi.org/10.1016/j.neurol.2017.06.024 